\title{
Appendix Neuroendocrine Tumor pT1 TNM Finding v8
}

National Cancer Institute

\section{Source}

National Cancer Institute. Appendix Neuroendocrine Tumor pT1 TNM Finding v8. NCI Thesaurus. Code C135147.

Appendix neuroendocrine tumor measuring $2 \mathrm{~cm}$ or less in greatest dimension. (from AJCC 8th Ed.) 